\title{
Letters
}

Author's reply to Brian Spooner's review of Reinhold Loeffler, Islam in Practice: Religious Beliefs in a Persian Village, Iranian Studies 29, no. 3-4 (Summer/Fall 1996): 401-406.

Of several distortions in Spooner's review of my book I feel that two need to be addressed because they involve another scholar's work. First, nowhere do I assert that Fredrik Barth "states that the Basseri are 'irreligious'," as Spooner states in his review (403). The citation of his name along with that of Mary Douglas (page 15 of my book) served to document the evolution of the idea which was then elaborated on page 245 . This section makes it perfectly clear that I do not attribute the term "irreligious" to Barth. Instead, it is Douglas whom I quote as using the term. And it is to her conception as well as to Spooner's "godlessness among nomads"1 that I object. In this objection I am fully supported by Barth himself, who in a recent conversation assured me that of course he does not consider the Basseri irreligious.

Second, I do not consider Barth's "influence on the field...unfortunate," as Spooner states in the review (403). Nowhere am I saying anything of the sort, and to construe such a meaning as a subtext in my discussion of Barth is totally unwarranted. On the contrary, I applaud Barth's pioneering research among the Basseri, which inspired a whole generation of anthropologists, including my wife and me. My objection to what some others have made of his research in no way warrants the conclusion that I consider his influence unfortunate. Nor must the subject of my book be taken to imply a slighting of Barth's approach in the Basseri case. I have myself worked along these lines, as a quotation of my work in the recent controversy over Barth's Basseri research shows. ${ }^{2}$

Reinhold Loeffler

Response to Loeffler:

I regret that Loeffler considers my review to contain distortions. I have read the book carefully, and am taking his words at what seems to me to be their face value. As I have written, I find much (but of course by no means all) that he has written about Islam to be at best misleading, sometimes in unfortunate ways, and in some cases erroneous.

With regard to the two specific points he raises, I have to stand my ground. I have reread the passages concerned (his pages 15 and 245 and my page 403) and

1. Brian Spooner, "The Cultural Ecology of Pastoral Nomads," Addison-Wesley Module in Anthropology, no. 45 (1973): 39.

2. In a discussion between Burkhard Ganzer and Sue Wright in Man, New Series 29, no. 1 (1994): 183,185 . 
my interpretation seems to me inescapable, though I shall bear in mind that he does not wish to be read that way. I encourage others to read for themselves and form their own judgment.

Furthermore, his reference to an earlier work of mine is from a sentence that reads "Bart appears to be trying to explain away godlessness among nomads," which seems to me to have an unambiguous meaning which is opposite to what he wishes to attribute to it.

Finally, I think it is pertinent to point out that in the discussion Loeffler refers to in the journal Man Barth has questioned not so much the direct interpretation of his words as the gratuitous addition to those words (from unreliable sources) for the purpose of making a particular innovative interpretation. The correspondence, which is lengthy and extends over three issues in 1992 and 1994 could become a locus classicus for the debate between established representatives of scholarship at its best and current innovative endeavors which pursue new objectives. But it is important to note that the reference it contains to Loeffler is not to the book under review and bears no relation to the practice of Islam.

\section{Brian Spooner}

Department of Anthropology

University of Pennsylvania Museum 